\title{
HEALING THE PAST : A COMPARATIVE ANALYSIS OF THE WAITANGI TRIBUNAL AND THE SOUTH AFRICAN LAND CLAIMS SYSTEM
}

\section{Liesle Theron*}

Land is of great social and economic importance in both New Zealand and South African society. The large scale dispossession of the indigenous people in both countries has had drastic consequences for them. The attempts that are being made to address these grievances, and thereby reverse the effects of past injustices, reflect the current political situation in each country. This article is concerned with claims for restitution and the institutions designed to facilitate them the Waitangi Tribunal and the South African Land Claims Commission and Land Claims Court and investigates which aspects of such mechanisms are effective and what lessons they have to offer.

\section{POLITICAL CONTEXT}

In the New Zealand and South African colonies the settlers soon came into conflict with the indigenous people over land. The result was war and land confiscation. Beyond that fact the colonies differ dramatically. While most indigenous grievances in New Zealand date back to those early times, the injustices in South Africa continued to escalate. In New Zealand, the survival of the Maori and particularly of their culture was soon jeopardised by war, disease, amalgamation policies, and loss of land - their means of maintaining a dignified existence as a nation. In South Africa, the indigenous people remained in the

This paper was submitted as part of the LLB(Hons) programme at Victoria University of Wellington, 1997. 
majority and it was a government policy of segregation, racism and subjugation, often implemented by legislation, from which the present grievances arise.

Maori claims today are based on the Treaty of Waitangi, ${ }^{1}$ which, because it is considered an international treaty, is unenforceable in the domestic courts unless it is incorporated into statute. ${ }^{2}$ Although there is much controversy over what it imports, there is no doubt that the Crown has repeatedly breached it. Following Maori activism in the 1960s and 1970s when they tried every avenue to have their grievances heard, the Waitangi Tribunal was set up in 1975 to address claims against current government policy, actions and legislation. It was only 10 years later, in 1985 that the Tribunal's powers were extended to the main land grievances - Crown acquisitions of land since $1840 .^{3}$

The events leading to the current situation in South Africa are more complex. White domination was ensured by an unrepresentative legislature and laws enacted which deprived black South Africans of their economic and social standing. The system of apartheid which was implemented in full scale when the National Party came to power in 1948 entrenched this status quo. Black people were removed from their land to homelands en masse and their movements were regulated by the pass system. The extent of the indignities they suffered as a people are only coming to light today to a large extent due to the work of the Truth and Reconciliation Commission.

An important point to note in a comparison of the New Zealand and South African contexts is that of ethnicity and tribalism. In South Africa they are associated with a history of racism and divide-and-rule politics, while in New Zealand despite causing some problems, they have played a role in rebuilding Maori identity. ${ }^{4}$

When it became clear that the machinery of the apartheid Government could not run

1 The agreement signed between the Crown and Maori for colonising the country. It sought to provide for settlement in return for the assurance of benefits for Maori and the maintenance of their interests. It can be found in the First Schedule of the Treaty of Waitangi Act 1975.

2 Hoani Te Heuheu Tukino v Aotea District Maori Land Board [1941] AC 308, 324. In New Zealand Maori Council v Attorney-General [1987] 1 NZLR 641 the orthodox position was acknowledged but left open as an issue which still needs to be considered, but the Privy Council in New Zealand Maori Council v Attorney-General [1994] 1 NZLR 513 appeared to accept it as the currently held view. In Huakina Development Trust $v$ Waikato Valley Authority [1987] 2 NZLR 188 the Treaty was referred to as a background constitutional fact.

3 Treaty of Waitangi Amendment Act 1985.

4 See T W Bennett "Redistribution of Land and the Doctrine of Aboriginal Title in South Africa" (1993) 9 SAJHR 443 and E T J Durie "South Africa : A New Zealand Maori View" June 1993 (unpublished - available at the Waitangi Tribunal) 2-5. 
indefinitely, the National Government under FW De Klerk introduced reforms which ultimately led to the first general election of April 1994 and the establishment of the transitional Government of National Unity. An Advisory Commission on Land Allocation had been established in the final days of the National Government's rule ${ }^{5}$ but under the new regime land reform began in earnest. It was identified as a pivotal element in the Reconstruction and Development Programme. The new government pledged to redistribute 33\% of South Africa's land over the following five years. ${ }^{6}$ The Restitution of Land Rights Act 1994 (1994 Act), enacted less than 8 months after the new government took over, ${ }^{7}$ was the first major reform legislation proposed by the new government. The priority given to dealing with this issue was partly due to the importance attached to land in the reform process and partly to the "very real threat of illegal reoccupation of land by dispossessed communities". ${ }^{8}$ Although it is seen as an important part of the healing and reconciliation of the nation, ${ }^{9}$ it is only one of three limbs of a much wider policy. ${ }^{10}$ It has been followed by measures ${ }^{11}$ which provide for the government's second programme land tenure reform (the creation of secure rights in property for those whose possession is insecure - and for the third programme of redistribution (to provide land for the dispossessed through community

5 In terms of s91 of the Abolition of Racially Based Land Measures Act 105 of 1991. It was an inadequate system which did not achieve much because it failed to provide for payment of compensation and there was no judicial alternative under the procedure. See L Albert "Land" Chapter 10 of N Boister (ed) (1993) 4 South African Human Rights Yearbook (Centre for Socio-Legal Studies, Durban, 1994)157, 153 who suggests it was simply a way of buying time in the light of increasing pressure about land, before the next government took over.

$6 \quad$ T Cohen "Land and Housing" Chapter 8 of Ronald Louw (ed) (1995) 6 South African Human Rights Yearbook (Centre for Socio-Legal Studies, Durban, 1996) 131, 142.

7 AJ Van der Walt "Land reform in South Africa since 1990 - an overview" (1995) 10 SAPL 1, 19.

8 Above n6, 143-144. See also W du Plessis and N Olivier "Land : new developments 1993/1994" (1994) 9 SAPL 179, 183 who refer to threats of communities, whose claims were being considered by the Commission on Land Allocation, to invade the land if their claims were not granted "within the immediate future".

9 Press release issued by the Chief Land Claims Commissioner, February 1997 "Media statement on a request to all government institutions and private developers to consider the restitution process in their actions".

10 D Hanekom (Minister of Land Affairs) "Land Rights, Property and the Constitution" Paper delivered at a workshop held by Theme Committee 6 of the Constitutional Assembly on 'Land Rights and the Constitution' Cape Town, 1 August 1995, 1 (available at the Waitangi Tribunal). According to Cohen above n6, 144, the 1994 Act effectively allows only a third of the 3.5 million people forcibly removed to seek redress.

11 Land Reform (Labour Tenants) Act No 3 of 1996. 
controlled processes). ${ }^{12}$ The government's policy is forward looking, ${ }^{13}$ its goal equitable access to land for all South Africans. ${ }^{14}$

Another important feature of the South African system is the role of the new Constitution. The 1994 Act was passed pursuant to and was required by the 1993 Interim Constitution which set out both a right to property and to restitution. ${ }^{15}$ The purpose of the 1994 Act was to set up a Land Claims Commission (the Commission) and a Land Claims Court (the Court).

The South African system is, therefore, constitutionally based and a government priority. It follows that the Commission and Court have considerable powers and sanctions. The Waitangi Tribunal can be said to be similar to the extent that the Treaty of Waitangi is seen as a constitutional document. ${ }^{16}$ The reality, however, is that it is an unenforceable international treaty, in a system of parliamentary sovereignty where the indigenous people it protects are in the minority. Real power lies with the predominantly Pakeha government. ${ }^{17}$ These stark facts may, however, obscure a further reality and that is that despite its ostensible lack of power and the fact that many of its recommendations conflict with the interests of the government, Waitangi Tribunal recommendations have been given much weight. They are usually implemented, if not fully at least to some extent. With the advent of MMP, the balance of power has changed and Maori parliamentarians have a more dominant role in Parliament. Despite calls for its disbandment on occasion, ${ }^{18}$ as an institution the Waitangi Tribunal has become firmly

12 About R316 million was made available for the scheme (above n6, 144).

13 Compare the description by E T J Durie "Welcome" (1995) 25 VUWLR 95, 96 of the New Zealand claims process as "futures directed".

14 Hanekom above n10, 1.

15 It provides for a restitution of rights in land to persons or communities dispossessed under or for the purpose of furthering the objects of any racially based discriminatory law.

16 See K Keith "The Roles of the Tribunal, the Courts and the Legislature" (1995) 25 VUWLR 129 at 131 where he calls it "the foundation document of New Zealand" and at 139 where he discusses how to the extent that the Treaty is a limit on the power of Parliament it is possible to argue that the Treaty along with the New Zealand Constitution Act is in fact New Zealand law.

17 ACT leader Richard Prebble calls the Waitangi Tribunal "a holding pen for Maori grievances, a way of pretending the issue is being addressed without upsetting anyone by actually doing anything". "ACT wants Waitangi Tribunal abolished" Dominion, Wellington, New Zealand, 7 May 1996, 2

18 Above n17 where Prebble calls for its immediate abolition and suggested that no more treaty claims should be allowed after the year 2000. See also text below at n104. 
entrenched as part of the system. ${ }^{19}$

\section{FUNCTIONS}

Section 5 of the Treaty of Waitangi Act 1975 indicates that the Tribunal's functions are to make recommendations on claims relating to the practical application of the Treaty and to determine whether certain matters are inconsistent with the principles of the Treaty. It has exclusive authority to determine its meaning and effect. ${ }^{20}$ This function of creating Treaty jurisprudence is important considering that the Court of Appeal has said that Tribunal opinions should be given much weight. ${ }^{21}$ The opinions are, however, not binding though, conversely, court decisions bind the Tribunal. ${ }^{22}$ Section 8 gives the Tribunal jurisdiction to examine and report on any proposed legislation specifically referred to it. The Tribunal also performs an "educative function" 23 of "explaining a Maori world to a predominantly western society" ${ }^{124}$.

The purpose of the Restitution of Land Rights Act 1994 (SA) is to restore rights in land to persons or communities dispossessed under or for the purpose of furthering the objects of any racially based discriminatory law. It is "designed to promote the protection and advancement of persons, groups or categories of persons disadvantaged by unfair discrimination, in order to promote their full and equal enjoyment of rights in land". ${ }^{25}$ This formulation addresses land directly and is more practical, reflecting the fact that the Act is an instrument in a larger reform programme.

The Tribunal is responsible for the whole process, leaving only the implementation (except for mandatory orders) and therefore the practical outcome to the Crown. The South African system, by comparison, divides the same functions between (1) the Commission (which is responsible for the lodgement, screening and solution by

19 See R P Boast "The Waitangi Tribunal : 'Conscience of the Nation', or just another court?" (1993) 16(1) UNSWLJ 223, 223 who says there is "little doubt that on the whole the Tribunal commands widespread respect and legitimacy" and refers to Sharp's suggestion that it is the second most important institution after Parliament.

Whether this has happened in practice is questionable considering that, for instance, following the Court of Appeal decision in New Zealand Maori Council v Attorney-General [1987] 1 NZLR 641, the Tribunal changed its view so that it now holds the Treaty to be one of cession.

21 Above n20, 661, per Cooke P.

22 Pbove n20, 689, per Somers J.

23 B Wilson "Introduction" (1995) 25 VUWLR 91, 91.

24 E T J Durie "The Waitangi Tribunal : Its Relationship with the Judicial System" [1986] NZLJ 235, 237.

25 See the long title of the Restitution of Land Rights Act 1994. 
administrative or mediatory procedures of claims, and investigation and monitoring of the process up to referral to the Court); (2) the Minister of Land Affairs who checks the feasibility of a restoration of a right in land, and (3) the Court which rules on restitution or compensation, and costs. Combining most of these functions in one body seems ambitious but the Tribunal has acquitted itself well. The backlog it is facing is, however, hardly surprising.

\section{AIMS}

In South Africa it is hoped that the process will be completed in five years. ${ }^{26}$ Considering the number of claims which the system is likely to have to deal with in light of the number of people who would be eligible in terms of the Act (a third of 3.5 million) ${ }^{27}$ as well as the time it has taken the Tribunal to work through its relatively few cases, it would do well if it achieved this goal. ${ }^{28}$ Progress has been slow ${ }^{29}$ and because of the volume of claims ${ }^{30}$ and number of researchers available, projections have been made that just to complete research into all the claims could take 15 years. ${ }^{31}$ In comparison, the Waitangi Tribunal has relatively few claims to deal with. Almost 690 have been lodged, the majority of which are historical ${ }^{32}$ but by grouping several for contemporaneous inquiry according to geographical districts, the major claims can be disposed of in

26 In the Land Claims Commission's First Annual Report (CTP Book Printers, Cape Town, 1996) 4, Seremane expresses expectation and hope with regard to completion in the allotted five years or "at least reasonably soon afterwards". New claims can be lodged until 30 April 1998.

27 Above n6. See also The Transvaal Agricultural Union $v$ The Minister of Land Affairs and the Commission on Restitution of Land Rights (1996) 12 BCLR 1573 (CC), where Chaskalson P at para 42 said that the first respondent's (Minister of Land Affairs) allegation that over 10000 claims, some from communities, have already been lodged and more are anticipated, is not surprising.

28 See the November 1994 Maori LR at 8 where an extract from the South African Financial Mail, which said that 95 rural communities and 110000 urban families affected by apartheid laws are expected to have claims is cited. The editor Tom Bennion comments that despite the fact that "in South African terms, the Act affects few people and is expected to cost little to implement,... [e]xperience with claims processes here and in other countries suggests the estimates as to cost and time are optimistic".

29 C Walker (regional land claims commissioner) "[Re]settling old scores : Land Restitution in KwaZulu Natal" (1996) 13:3 Indicator SA 46, 47.

3013,171 were registered by the Commission by 22 January 1997. Marissa Greeff "editorial" (1997) 4:1 Land Info 2. 7095 were registered by 31 March 1996 (Walker above n29).

31 Above n26, 12.

32 There is a backlog of more than 450 ("Call to use Waitangi claim precedents" Evening Post (Wellington) 30 April 1997, 15). 
approximately 30 inquiries. ${ }^{33}$ According to Chief Judge Durie, with adequate resources these could be dealt with by the year $2000 .{ }^{34}$ It is hoped that the claims process will be streamlined by the National Overview Report ${ }^{35}$ released recently. By drawing historical evidence together to categorise claims it is intended to assist the Tribunal move more swiftly through the hearing and resolution process. ${ }^{36}$

Both the South African and New Zealand systems are therefore operating within the same time frame but with vastly different workloads. Whether or not they succeed in the anticipated time will depend on the resources that are available to them.

\section{NATURE}

The most striking difference between the two systems is that while the South African system encompasses many of the investigatorial and mediatory functions of the Tribunal in its commission, it has a land claims court with the binding powers of such an institution. The Tribunal, as a commission of inquiry, has only recommendatory powers (except in a few areas); ${ }^{37}$ its inquisitorial, bicultural and inter-disciplinary nature has proved it to be well-suited to the type of claims it is responsible for dealing with.

The legislation for each of the Tribunal and the Commission indicates that their functions, duties and responsibilities are to be carried out in a pro-active manner and the Commission in particular has been given exclusive powers of delegation and appointment of people to assist as well as wide-ranging investigatory and monitoring powers.

Two interesting points which arise in this context are (1) whether a court is the appropriate mechanism for dealing with such land claims, and (2) the extent to which the Waitangi Tribunal's resumptive powers alter its nature as a commission of inquiry.

33 Waitangi Tribunal Re Ngai Tahu Claim - Wai-27 (Unpublished memorandum \#AB81, 17 March 1995) 4. See also Durie "Background Paper" (1995) 25 VUWLR 97, 99.

34 Above n33. See also "Scrapping of Waitangi Tribunal nonsense" Evening Post (Wellington) 7 May 1996, 1 where Minister of Treaty Negotiations, Doug Graham indicated the government was still confident that most claims would be dealt with by the year 2000 .

35 A Ward National Overview : Tribunal Rangahaua Whanui Series (GP Publications, Wellington, 1997).

36 Durie is quoted as saying it is "by far the most exciting and important development to have occurred since the historic claims process was started by Government in 1985" in "New Report Streamlines Claims" Te Manutukutuku no 41 (Huia Publishers, Wellington, 1997) 1.

37 According to $\mathrm{cl} 8$ of sch 11 of the Treaty of Waitangi Act all provisions except ss11 and 12 of the Commissions of Inquiry Act 1908 apply - it has all the powers of a commission of inquiry except the power to award costs. Boast above n19, 243 calls it a "hybrid between an administrative tribunal and a commission of inquiry". 


\section{A Legal vs Political Solution}

The report of the Land Claims Court Working Group (SA) discusses some of the disadvantages of a court. ${ }^{38}$ Firstly, in the context of restitution of land rights there is the danger that the legal system, because of its tendency to conservatism, would favour the title holder and avoid disturbing the status quo. This argument is of more relevance to South Africa, because the Waitangi Tribunal's jurisdiction with regard to land is limited to claims to state land. ${ }^{39}$

Secondly, because of the expense and complexity of legal proceedings, a rich and well-educated party would have an advantage. This is particularly significant in South Africa where most claimants, by virtue of the process which deprived them of their land, are in a lower socio-economic position: both poor and uneducated. ${ }^{40}$ It is also suggested that the adversarial system empowers lawyers instead of the aggrieved parties. ${ }^{41}$ Considering the dominance of lawyers in the Waitangi Tribunal proceedings, it is likely to be a problem there too.

Thirdly, the Working Group also suggests that a direct practical solution may be preferable. The resolution of such extensive historical injustice is perhaps not suited to the judicial process. Final settlement by the New Zealand Tribunal is made both undesirable and impossible by the view that rights belong to future as well as present generations (and therefore cannot be for sale), wider issues of Maori participation in national policy-making, the fact that many claims are political matters and the nature of the Treaty as an ongoing social and political contract. ${ }^{42}$ There is also Canadian criticism that courts "are insufficiently representative to handle native perspectives and that the legal discipline is overly restrictive of historical and anthropological opinion." ${ }^{43}$

38 Land Claims Court Working Group Preliminary Report to the ANC Land Commission July 1992, 2 - 3 (available at the Waitangi Tribunal). See E Swanson "A Land Claims Court for South Africa : Report on Work in Progress" (1992) 8 SAJHR 332 for a summary of the same material.

39 Private land was only excluded from its powers as recently as 1993 and it is interesting to note that until then no serious attempt had been made to include private land in recommendations precisely for this reason according to Bennion. See below n106.

40 This is counteracted by the legal aid for which both systems make provision. The Tribunal, in particular, has gone to great lengths to make the process more accessible also by modifying its procedure.

41 "What others are saying" Evening Post, Wellington, New Zealand, 15 May 1996, 8.

42 Above $\mathrm{n} 24,236$.

43 Above n33, 100 . 
On the other hand, the judicial tradition brings a number of important attributes to such a process. Its immunity from government interference and the order and certainty associated with it are crucial considering the emotionally charged nature of land claims. Parties need to have faith in the system - it must be seen as legitimate, accessible, fair and consistent. It needs to have credibility as a body with enough power to achieve its purpose.

Both the Working Group and Durie suggest that the court model could be modified to be an appropriate mechanism for redress of such grievances. The Working Group's solution $^{44}$ is to provide legal aid, instruct the court that its purpose is to restore land ${ }^{45}$ and restrict its jurisdiction to a specific type of claim. ${ }^{46}$ It concludes that a judicial process based on values common to both parties and where they each have an opportunity to present their claim would be the best way of achieving resolution.

The two land claim systems ultimately incorporate both judicial and political responsibility. The Waitangi Tribunal has a "semi-legal approach" 47 which prevents the development of the Maori - Pakeha relationship being left entirely in the hands of the judiciary while giving the indigenous rights more protection than mere political appeal. The South African system has two tiers which combine the advantages of an administrative body with the strengths of a court of law. In New Zealand although the functions of research (done by the Waitangi Tribunal Division) and hearing (by the Tribunal itself) are separate, because the Division is at the direction of the chairperson of the Tribunal, this distinction is blurred. Arguably by the time the research is finished the Tribunal is not as impartial as a separate body. The South African system may therefore, be preferable in this respect. Even if those hearing the claims know little about them, they are appointed for their expertise in relevant areas instead of their impartiality - prior knowledge and involvement

\section{Above n38, 2}

45 By requiring the court to consider specific factors and building a preference for restitution into the process by a statement in the legislation or even instructing it to apply a presumption in favour of restitution.

46 Forcible removals against their will, not necessarily by physical force (by apartheid laws and policies).

47 Above n24, 237. See also E T J Durie and G S Orr "The role of the Waitangi Tribunal and the Development of a Bicultural Jurisprudence" (1990) 14 NZULR 62, 65 where they point out that in advising government on matters of policy it resembles a commission while it is court-like when it comes to its duties to make finding of fact and interpretation in order to decide whether a claim is well-founded. 
which is less likely to disqualify them than in a judicial context. Others would argue that a thorough knowledge of the background is not only desirable for, but essential to, a fair decision. $^{48}$

In this difficult, complex and emotional area no mechanism could provide the perfect solution. Nothing will prevent the inevitable resentment among plaintiffs who lose their claims. ${ }^{49}$ The Working Group concludes that a legal solution would be more likely to reduce tension than a "sweeping political approach which [does] not take into consideration the particularities of each situation." ${ }^{50}$ In the Waitangi Tribunal, perhaps such a solution has been found. Durie and Orr call it "a single jural order with bicultural capabilities" - "the option most expressive of the Treaty and best suited to the New Zealand milieu". ${ }^{51}$

\section{B The Mandatory Powers of the Tribunal}

In the context of broader settlements the Waitangi Tribunal's powers have been extended so that its decisions are binding in specific areas. The Tribunal now has the power to order the return of land transferred under the State-Owned Enterprises Act even where it had been sold to a third party, ${ }^{52}$ certain education land, Crown forest lands and the assets of the state-owned railway system. ${ }^{53}$

Arguably these powers bring the Tribunal into line with an ordinary court of law. If they lead to review proceedings in the High Court, the Tribunal may be forced to take a more legalistic approach. ${ }^{54}$ Despite suggestions by Durie that when substantial Crown assets are in question, a higher evidential standard, loss quantification and increased legal argument are required, ${ }^{55}$ the Tribunal has said it can find no support for adopting a

48 Durie above n24, 237 describes how while the legal view may be that the best arbiter is removed from the claim, the Maori tradition prefers a leader closely involved and familiar with the circumstances.

49 Waitangi Tribunal claimants are rarely unsuccessful. The challenge to the Kiwifruit Marketing Board's monopoly on kiwifruit exports is one of very few examples (Kiwifruit Marketing Report Wai-449).

50 Above n38, 3.

51 Above n47, 63.

52 The Treaty of Waitangi (State Enterprises) Act 1988.

53 By virtue of the Education Amendment Act 1990, Crown Forest Assets Act 1989 and New Zealand Railways Corporation Restructuring Act 1990.

54 Above n23, 191.

55 See above n33, 100. See also Memorandum \#2.59, Wai-46, Record of Inquiry, 13; Memorandum \#2.104, Wai-46, Record of Inquiry, 4, 6 (with regard to the Eastern Bay of Plenty Claims) and 
higher standard of proof with regard to binding recommendations and that having the power to make binding recommendations among its wideranging powers does not make it a court. The Tribunal will simply follow the common sense principle that greater care should be used to assess more serious issues. ${ }^{56}$ There is also no right of appeal and the 90 day period between the interim recommendation and its confirmation ${ }^{57}$ has proved an important opportunity for negotiation because the claimants are in a powerful bargaining position.

The Waitangi Tribunal has avoided exercising its new powers so far and whether it ever will is uncertain after the furore surrounding the preliminary Muriwhenua report. The possibility of binding recommendations in respect of Crown forests and state enterprise assets sparked response from politicians that it would be "disastrous and...could bankrupt the country"58 and "could explode the Government's $\$ 1$ billion settlement budget and scuttle future treaty claim settlements". 59 There was even talk of restraining the Tribunal by legislating away its resumptive powers. ${ }^{60}$ Another concern was that conservation land would have to be used as part of the settlement. ${ }^{61}$ This outcry was met by protests that the Tribunal makes recommendations very carefully and publicly $^{62}$ and by concern about government interference in the Tribunal process. Both Maori and the government had given up rights in the settlements from which these powers emerged but the government has the upper hand because it can legislate those powers away and is likely to do so if they are not used with restraint.

Because of its dependence for its existence on government it may be preferable that the parties negotiate a settlement and that the Tribunal avoids being forced into a corner. The consequences of a mandatory order may be devastating for its credibility. "The

Muriwhenua Claim - Wai-45:I6 cited in Waitangi Tribunal Directions of the Presiding Officer in re Ngati Turangitukua - Wai-84 (\#E1, 25 March 1997) 40.

Above n55 Directions of the Presiding Officer in re Ngati Turangitukua 42, 44.

57 Section $8 \mathrm{~B}(3)$ of the Treaty of Waitangi Act 1975.

"The claim is sound : but can it be settled" The Daily Post, Rotorua, New Zealand, 3 April 1997, 4 (quoting Winston Peters).

59 "Tribunal threat over return of land heads for a showdown" The Dominion, Wellington, New Zealand, 27 March 1997, 2 (quoting Minister of Treaty Negotiations, Doug Graham).

60 "Unpalatable finding from the Far North" The Nelson Evening Mail, Nelson, New Zealand, 27 March 1997, 11 (quoting Hon Doug Graham).

61 Above n60

62 "NZ can't afford to return state forests to iwi : Peters" The Waikato Times, Hamilton, New Zealand, 25 March 1997, 2 (quoting Morrie Love). 
tribunal may have the teeth; better for all if it never has to bite". ${ }^{63}$ On the other hand, greater Maori influence with MMP is likely to prevent any action being taken against the Tribunal and to put pressure on the Tribunal to use this power it has had for ten years. It is equally important to its credibility with Maori that it prove itself to be more than a paper tiger. Any action by the government would be a breach of the settlement following the "Lands" case $^{64}$ (in the case of state-owned enterprises land) of which these mandatory powers formed part. Forced return looks to become a reality in the near future in the Turangi claim which is seen by all sides as an important test case. ${ }^{65}$

\section{COMPOSITION}

The Waitangi Tribunal consists of up to 16 Pakeha or Maori members and an ex officio chairperson, the Chief Judge of the Maori Land Court. The majority no longer has to be Maori (by a 1988 amendment) and the racial imbalance that has existed has come under criticism. ${ }^{66}$ Members are often qualified in history or law and can be elders, businesspeople or others of standing. According to Chief Judge Durie, knowledge and expertise in an area is more important than judicial expertise. ${ }^{67}$

When deciding appointments, the partnership between the parties to the Treaty must be considered. ${ }^{68}$ Durie and Orr point out the significance of the inclusion of this principle in the constitution of the Tribunal : "Few treaties (if any) between native and settler groups fall to be interpreted by a body representative of both sides". ${ }^{69}$

In South Africa, section 8(2) of the 1994 Act seeks to ensure that the staff of the Commission are broadly representative of the South African population. ${ }^{70}$ The Chief Land Claims Commissioner may make ad hoc appointments of persons with specialist or expert knowledge on the issues or in conflict resolution to assist the Commission. The Court is composed of a President ${ }^{71}$ and such additional judges as he may appoint. ${ }^{72}$

63

64

65

66

68

69

70

71

"Hard iwi work ahead" The New Zealand Herald, Auckland, New Zealand, 31 March 1997, A12.

Above n20.

"Fatigue sets in over Waitangi" The Sunday Star Times, Auckland, New Zealand, 24 August 1997, C2.

C Wickliffe "The Waitangi Tribunal : A Critique. The need for a Regional Human Rights Mechanism" vol 2 no 4 New Zealand Law Librarian 125, 127.

Durie above $n 4,12$.

Section 4(2A)(a) of the Treaty of Waitangi Act 1975.

Above n47, 63.

There is a Chief Land Claims Commissioner (Joe Seremane) and regional ones.

Fikile Bam is Judge President. 
Appointees need not be lawyers but must have a legal background. The Court may appoint assessors to assist it.

\section{LODGING A CLAIM}

Claimants who approach the Waitangi Tribunal must be Maori. At least one individual must be named. The claim must refer to actions of the Crown, the Treaty must be mentioned and some form of harm or loss must have been suffered..$^{73}$ In South Africa, any person or direct descendant, or community dispossessed of any right in land by virtue of a racially discriminatory law can bring a claim to the Land Claims Commission. ${ }^{74}$

The Waitangi Tribunal has jurisdiction over claims referring to present and future as well as past Crown actions while in South Africa only historical claims are at issue (although in the South African context "historical" is used to refer to claims involving dispossession before 1913). ${ }^{75}$ There the aim is to make peace with the past, putting an end to a period of history. The Tribunal has a greater focus on currency of issues and no finite case load - making it more than a body to finalise grievances.

Issues arise concerning community claims and problems with representation, the significance of the dates from which claims could arise, the effect of compensation that has been paid, what constitutes an interest in land and the implications of the South African system's inclusion of private land.

\section{A Group Claim Issues}

The Land Claims Working Group highlights the importance of rigorous notice procedures in ensuring everyone involved is represented. ${ }^{76}$ The South African Commission faces substantial obstacles in widespread illiteracy, the diversity of languages and the distances over which the claimants may have been dispersed. The

72 Supreme Court judges may be seconded to the Court if necessary.

73 In Durie's "Background Paper" above n33, he refers to three categories of claim : historical (past Crown actions), contemporary (current Crown actions) and conceptual (ownership of natural resources).

$74 \quad$ Unsuccessful claims (including those predating 1913, land lost through private transactions and land acquired by the state for public purposes unlikely to be construed as racist) are forwarded to the Minister of Land Affairs by the Commission with recommendations as to how they should be addressed.

75 See Walker above n29, 49 and above n26, 11.

76 Section 11(5) of the 1994 Act, above n25, allows claimants to apply to the Court for permission to lodge a claim in respect of land which has already been dealt with by the Court. This does not mean that notification is any less important especially in the interests of finality - for efficiency and stability of ownership. 
New Zealand situation, in comparison is simple and manageable, and notification has not been problematic.

Mechanisms are needed to ensure representatives are selected by and are accountable to the group as a whole. Many of the problems could be dealt with by the way in which the award is made whether to the group as a whole, to the people or the descendants of the people who were members of the tribe and lived on the land at the time of removal or to all who have an intrinsic claim to the land. ${ }^{77}$ The Court has a wide discretion as to how the land or right is to be held by the community or how compensation is to be paid to them. ${ }^{78}$ The Tribunal which has had far more practical experience in this area, ensures, when a successful claimant is a group, that there is a corporate structure in place which will be accountable to the beneficiaries, subject to audit and which will protect minorities. $^{79}$

The New Zealand system having dealt with such issues for a while now may have established some practical solutions from which South Africa could take guidance. According to Durie representation has been a major impediment to the resolution of claims. ${ }^{80}$ The question arises in three areas. ${ }^{81}$

The first instance is when there are a number of overlapping and conflicting claims in respect of one area (customary representation). The Waitangi Tribunal has emphasised the need for each group to first have the opportunity to present their claims on their own maraes or places of their choosing ${ }^{82}$ and stated that section $6 \mathrm{~A}$ under which the Waitangi Tribunal can refer such issues to the Maori Appellate Court by way of case stated, is unduly limiting. It has suggested that extensive overlaps and "discrete tribal enclosures within larger compacts" are not uncommon. ${ }^{83}$

The second area where representation is at issue is deciding at what level (hapu, iwi or national) matters should be settled.

Thirdly, establishing which bodies or associations should represent Maori groups

77 Above n38, 17.

78 Above n25, s35(3).

79 Durie above $\mathrm{n} 4,15$.

80 Durie above n33, 102.

81 Discussed by Durie above n33, 102.

82 Direction, Memoranda on Procedure, Evidence and Issues in the Inquiry into the Ngati Awa, Tuwharetoa and other Claims of the Eastern Bay of Plenty (Waitangi Tribunal, 11 November 1994) 10.

83 Above n82, 18. 
today is an important issue. Section 30(1)(b) Te Ture Whenua Maori Act 1993 sets out a procedure for determining representation. The Maori Land Court has looked to current arrangements which have developed from old principles and focussed on the importance of unity. ${ }^{84}$ It is a very slow process (which can be pursued to the Privy Council) and the outcomes are not always satisfactory.

Tom Bennion ${ }^{85}$ points out a conflict between section 30 (which allows a group to secure an order for negotiations over a claim and a right to lay future claims) and section 6A of the 1975 Act (involving the situation where another group from the same iwi lays a claim before the Tribunal and boundary questions). The historical position (section 6A) is an integral part of determining the contemporary position (section 30). To avoid overlap and conflicting decisions, he suggests an amendment which would reconcile the two by allowing the Tribunal to determine whether claimants before it adequately represent the group on whose behalf the claim is made. "Ultimately, given the dynamic nature of Maori society and institutions, a policy for determining representation which is too rigid would be undesirable and might even be regarded as a breach of the Treaty. There should always be an allowance for new situations to produce new models and leaders, as the experience of the past few decades have shown." 86

Durie is of the opinion that these are Maori issues which should be resolved by Maori policy. ${ }^{87}$ The problem he points out is that there is no structure to develop Maori policy in a democratic way.

Most questions of standing, however, are worked out or decided by the Tribunal during the hearing of the claim. The commission of inquiry process, the Waitangi Tribunal's intensive knowledge of the people and areas, and the other claimants' and the Crown's opposing argument would soon bring any problems to light. ${ }^{8}$ Instead of dealing with standing and representation in the conventional way at the beginning, the Tribunal has found the later stages to be a better time because by then the "groups have had a chance to caucus and to settle". ${ }^{89} \mathrm{New}$ Zealand law, recently, has allowed claims without questioning the class or group too much as long as it is a legitimate claim, and in

See In re Tararua District Council 138 Napier MB 851 Nov 1994.

"Who represents Maori Groups?" [November 1994] MLR 1, 1.

Above n85, 1.

Above n13, 94 .

A good illustration is the Chatham Islands claim where the Moriori went to great lengths to present evidence of their genealogy in response to Maori challenges that they no longer existed as a people.

Durie above n4, 14. 
no forum is this more true than the Tribunal where the formal rules of procedure and evidence are not strictly applied and it is soon clear how valid a claim is.

In New Zealand it is possible to assemble everyone on a marae at one time and there the sanction of the group would make it difficult for people with spurious claims or no mandate to proceed. ${ }^{90}$ Challenges are also made privately or at the beginning on the paepae (outside) and in Maori. This approach would not be so easy in a South African context where the question would arise on a greater scale (in terms of distances and number of people ${ }^{91}$ ) and would be in many ways more complex (in terms of history of dispersion). The basis on which the person lodging the claim contends he or she represents the community must be declared in full and be accompanied by an appropriate resolution or document in support. ${ }^{92}$ Both those who should be included amongst the claimants and the individuals who constitute appropriate representatives would probably be firmly established at the outset by the Commission, in its research and investigations, and when referring a claim to the Court, it has to provide a document which among other things contains a list of the parties who ought to have the right to make representations to the Court. ${ }^{93}$ It seems to have also more relaxed rules with regard to standing, only requiring the claimant to be a person or community contemplated in section 121(2) of the Constitution. ${ }^{94}$ A tribe only needs to show it is a "community" as contemplated by section 1 of the 1994 Act : "any group of persons whose rights in land are derived from shared rules determining access to land held in common by such group, and includes part of any such group".

\section{B Dates}

The cut-off date for claims to the Waitangi Tribunal (6 February 1840) is self explanatory, the whole process being based on the Treaty. The choice of 1913 for South African land claims is not quite as obvious. ${ }^{95}$ The Interim Constitution of 1993 referred to

90 Durie above $\mathrm{n} 4,14$

91 See text at n30. Compare the number of claims already made with the Commission (more than 10 000) to the Tribunal which has approximately 650 historical claims on its register, of which according to Durie above n33, 99 many can be grouped and some are duplicated. "It is estimated that the historical claims could be reduced to some 30 inquiries."

92 Under above n25, s10(3).

93 Above n25, s14(2)(c).

94 Above n25, s29(1) provides for any party listed in the document or with an interest in relation to s34 (which allows a government body which owns or has jurisdiction over land to apply to the Court for an order not restoring that land to the claimants) to appear before the court.

95 1948, as it symbolises the beginning of grand apartheid (the year the National Party came to power) was also discussed by the Land Claims Working Group above n38, 16. 
19 June 1913 as the earliest date from which to work. It was the commencement date of the Land Act 27 of 1913 which was the "first formal action to abrogate the property rights of Blacks" 196 and effectively relegated $80 \%$ of the population to $13 \%$ of the land by creating the black reserves and making black ownership outside those areas illegal. The removal and eviction of large numbers of people followed. The date was chosen despite the fact that many people were forcibly removed from their land at an earlier stage and acquisition of land analogous to that which took place in New Zealand had proceeded as broad colonial policy a century earlier. The Working Group warned that if claims were allowed to go too far back it could be dangerously divisive and could involve difficult problems of proof ${ }^{97}$ as well as probably making the expropriation of private land more difficult. According to Hanekom, ${ }^{98}$ by 1913 most dispossession had already taken place. Hence the importance of South Africa's other land reform measures.

Deciding which claims are "historical" (date back to before 1913) and therefore excluded has presented its own problems. In Zululand, for example, people lost indigenous rights of ownership before 1913 but continued to live on the land until the 1920s and 1930s when some was sold to white settlers or the 1950s onwards when some was made a conservation area. ${ }^{99}$

\section{Compensation}

The Land Restitution and Reform Laws Amendment Act 1996 (SA) provides that no person shall be entitled to enforce restitution if just and equitable compensation was paid. In New Zealand on the other hand, claims can still be sustained where land had been expropriated and market value compensation paid. This reflects the fact that the Waitangi Tribunal considers in a broad way, the impact of the loss, the question being "whether the people were unjustly removed from ancestral lands and whether they were in practice able to acquire other lands of equal value to them". ${ }^{100}$ The meaning of "just and equitable" still needs to be given substance by judicial interpretation in the South African Land Claims Court. In practice, therefore, the result in South Africa is likely to be the same.

S Hosking "Redistributive Land Policy : a Case Study" (1996) 64:2 SAJE 44, 71. See above n5 for criticism.

97 Above n38, 16. The "historical" claims, mainly lodged by tribal authorities or contenders for that status, involve the traditional rights and powers of chiefs and tribal councils which underlie much of the present political tension. They compete with claims by more recently dispossessed people. Usually the boundaries of the land claimed were contested to the same extent in the 19th century by other "tribes" as they are today. Walker above n25, 49-50.

98 Above n10, 1.

99 Walker above n29, 50.

100 Durie above n4, 15. 


\section{A Right in Land}

The 1994 Act refers to interests in land rather than land claims and does not require an interest in land to be a right recognised by law but indicates that it can be, for instance, a customary law interest or established by beneficial occupation for a continuous period of not less than ten years prior to the dispossession. ${ }^{101}$ The rights in question at the Waitangi Tribunal are those protected by the Treaty. In taking into account the Maori version, there has been much debate as to what is covered, especially by the word taonga (treasured things) which has been held to include language. ${ }^{102}$

\section{E The Implications of Claims to Private Land}

The fact that the South African system can investigate claims to private land involves a number of provisions which have no equivalent in the New Zealand regime. In particular the importance of ensuring that landowners do not take unilateral action selling, destroying or removing property as soon as their land becomes subject to a claim is addressed in section 11(8) which allows the Commission to draw up an inventory of assets, list of persons employed or resident on the land or report on the condition of the land.

The possibility of privately owned land being subject to claims to the Waitangi Tribunal $^{103}$ met with vehement public opposition, arguably even putting the Tribunal's continued existence into question, ${ }^{104}$ when in 1992, the Tribunal in its Te Roroa Report ${ }^{105}$ recommended the return of land which included private land. Although it seems this was an overreaction, ${ }^{106}$ the 1993 amendment Act was promptly passed, putting the issue beyond doubt. The result was a further restriction of the Tribunal's powers and awareness of the delicate tightrope the Tribunal walks between carrying out its objectives

101 Above n25, s1(xi).

102 Waitangi Tribunal Te Reo Maori Report - Wai-11 (Department of Justice, Wellington, 1986) adopted in New Zealand Maori Council v Attorney-General [1994] 1 NZLR 513, 514 (Privy Council).

103 There was originally no restriction on land which claims could cover or on the recommendations which the Tribunal could make regarding it.

104 "Time to scrap tribunal - Meurant" Dominion, Wellington, New Zealand, 27 May 1992, 2. His views, however, were rejected as "absurd" and only shared by a "small minority of 'rednecks' in caucus" ("Ministers turn down call to scrap tribunal" Dominion, Wellington, New Zealand, 28 May 1992, 2).

105 Waitangi Tribunal Te Roroa Report - Wai-38 (Department of Justice, Wellington, 1992).

106 Tom Bennion "Private Land and Maori Claims" (1991) 2 Terra Nova 51 points out that Maori did not necessarily want or expect private land to be returned and the Tribunal, reluctant to disturb titles of bona fide purchasers, had indicated that the Crown could negotiate for and buy private land but only if the owner was willing. 
and avoiding controversy by not provoking the public. This incident again showed that to some New Zealanders, the Tribunal's position is not inviolate and its removal not unthinkable. The farmers claimed that the Tribunal's recommendation had permanently lowered the value of their land and wanted the Government to buy the land at market value plus compensation. ${ }^{107}$ This highlights the importance of resolving claims in South Africa expeditiously so that landowners can deal with their land unhampered by the possibility of expropriation.

The two systems are similar in that the South African legislation provides for the registration of the claim in the deeds registry (section 11(6)(b)), and the 1988 amendment to the Treaty of Waitangi Act for the registration of a memorial against the certificate of title that the land is subject to resumption by the Crown. The Constitutional Court of South Africa has held that section 11(6)(b) does not in itself detract from the rights of a landowner who remains free to alienate or deal with the property, registration amounting to "no more than notice to the world at large that the land...is subject to a claim under the Act". Whether this is true in reality is arguable, ${ }^{108}$ and it is in this regard that the fear of its effect on the land's value also arises.

The potential infringement of a landowner's ownership rights has arisen in South Africa in the Transvaal Agricultural Union-case ${ }^{109}$ where the applicant contended that sections 11(7) and (8) which prohibit "obstruction of the claim" (which could include virtually anything done to or with the land) and providing for inventories, lists or reports to be drawn up, were inconsistent with sections 28 and 26 of the Constitution which protect the rights to acquire, hold and dispose of property, and to freely engage in economic activity. The Constitutional Court found that existing rights of ownership do not have precedence over claims for restitution. ${ }^{110}$

\section{F Formality}

If a claim is not lodged in the prescribed manner, the regional land commissioner can

107 "Meurant says scrap Waitangi Tribunal" New Zealand Herald, Auckland, New Zealand, 27 May $1992,5$.

108 The Commission has resorted to interdict proceedings to prevent conduct in disregard of the process and in its media statement, above n9, appeals for respect of the spirit of the Act after even local authorities were found to be going ahead with development of land under claim. It is also likely that as soon as land becomes subject to a claim, the consequent uncertainty would make it difficult to sell or use as security.

109 Above n27.

110 The court referred, at para 33, to sections 121 to 123 of the 1993 Interim Constitution which expressly sanction "and indeed require" the 1994 Act to take precedence. It held that the conflicting interests "are to be resolved on a basis that is just and equitable". 
condone it. ${ }^{111}$ Following the acceptance of the claim, the Commission assists in preparing and refining it.

The Tribunal, similarly, does not attach undue importance to the form of the applications which could make the process less accessible for many. The Tribunal keeps formalities in general, especially paperwork, to a minimum. ${ }^{112}$ Its objectives are to be orderly and efficient but also simple and informal.

\section{PROCEDURE}

\section{A The Proceedings}

Section 32(2)(a) of the 1994 Act allows the Court to conduct any part of any proceedings on an informal or inquisitorial basis. The implications of this provision may be comparable to the Waitangi Tribunal with its sui generis procedure.

The Tribunal, because of its nature as a commission of inquiry, has had and has made good use of the opportunity to adapt its procedure to the needs of the claimants and the subject-matter, by hearing claims on the marae of the claimant and following their protocol $^{113}$ As Durie and Orr point out, an overdependence on legal rules may be "inappropriate when catering to claims against certain broad socio-economic policies of the state or against Crown actions of the last century". ${ }^{114}$

The Tribunal has allowed the expansion, amendment and even substitution of claims and has dealt with issues not mentioned in the claim as filed. It does not require parties to be bound by their pleadings and, to ensure fairness, has striven to notify interested parties of any changes and allowed for adjournments as a result. ${ }^{115}$

Despite the undeniably innovative approach the Tribunal takes its uniqueness, as Boast $^{116}$ points out, may be overdrawn. It is governed by the same rules as other administrative tribunals with few modifications, is limited by rules of natural justice and

111 Above n25, s11(2).

112 P Temm The Waitangi Tribunal : The Conscience of a Nation (Random Century NZ Ltd, Auckland, 1990) 7 . The difficulty this might cause for the preparation of a defence is met by procedure whereby, after all the evidence has been presented for the claimants, experts consulted and the issues formulated, copies are given to all concerned and the proceedings are adjourned to give the Crown an opportunity to prepare a defence.

113 See Temm above n112, 7 ff for further detail.

114 Above n47, 64.

115 Durie and Orr above n47, 65 . 
to any outsider the process looks extremely formalised as it is heavily influenced by lawyers.

\section{B Rules of Evidence}

The Land Claims Working Group suggests that the only rule of evidence should be that the evidence must be relevant to the Court's decision (leaving it to the Court to decide whether it is relevant and admissible) because strict adherence to rules of evidence could be extremely prejudicial. ${ }^{117}$ The legislation has followed this approach making any "relevant and cogent" evidence admissible, including oral, hearsay evidence and expert evidence regarding the historical and anthropological facts relevant to the claim. ${ }^{118}$ The Court may give such weight to any evidence as it deems appropriate. ${ }^{119}$ These deviations from the formal rules of evidence are comparable to those in the Waitangi Tribunal ${ }^{120}$ but there, in the context of a commission of inquiry, they are less remarkable.

Relaxing the rules of evidence is important to allow the Court or Tribunal to get to the facts of each claim because the historical nature of the claims means the original parties may have died and the nature of the rights is likely to entail few direct records. It also, however, potentially creates a new set of problems and one of the issues which arose in the Muriwhenua claim was how to deal with a direct conflict between oral and documentary history. The Tribunal placed anthropological insights as to the values, norms and laws of Maori, Polynesian and comparable indigenous peoples above the oral tradition of the Muriwhenua Maori. Documentary records, largely in the government archives, were understood in the light of those two sources. ${ }^{121}$

\section{Emphasis on Negotiation and Mediation}

The Tribunal has the power to settle claims by mediation and filing a claim with it does not prevent claimants continuing negotiations with the Crown. The Tribunal can refer a matter to negotiation after a pretrial meeting or parties may choose to negotiate,

117 Above n38, 9

118 Above n25, s30.

119 Above n25, s30(3).

120 Clause 6(1) of the second schedule of the Treaty of Waitangi Act 1975 allows the Tribunal to receive as evidence, statements, documents, information or other matters that would otherwise be inadmissible.

121 B Oliver "Is bias one-sided?" (1997) 7:2 New Zealand Books 17, 17. He criticises the Tribunal's use of such an approach to find that because of the Maori understanding, there was a lack of mutuality in the pre-1865 transactions transferring land in the Muriwhenua rohe and they, therefore, do not amount to sales. Oliver suggests at 19 that the Tribunal should have stopped at the "array of less vulnerable arguments which lead to the same conclusion". 
after a full report on the facts of an historical claim, if it is well founded. Only if they decide not to do so or the negotiations fail is there a hearing on remedies and a report. ${ }^{122}$

In South Africa, negotiation and mediation is an integral part of the process. Before the Court hearing every opportunity for a negotiated settlement is explored. ${ }^{123}$ Only after the parties have agreed in writing that settlement by negotiation and mediation is impossible and the regional land claims commissioner certifies it is not feasible (or on the other hand agreement is reached) does it go to the Court. ${ }^{124}$ The claim is accompanied by a document which among other things, reports on the failure of any party to accede to mediation. ${ }^{125}$

The Land Claims Working Group puts such importance on this alternative that it goes as far as suggesting that incentives be built into the process to encourage negotiation. ${ }^{126}$ Clearly it is an attractive option. Not only is it practical, involving direct participation of parties, and economical, but it is also likely to avoid the win-lose result of a court hearing. Furthermore, in the context of indigenous claims, it affords the opportunity for the different cultures to learn to communicate with each other. It is perhaps therefore appropriate especially for the Tribunal where the focus is on the enduring relationship between the Treaty partners.

\section{Feasibility}

In the New Zealand system, the feasibility of returning a piece of land or land right would be established and taken into consideration by the Tribunal during its investigations into the claim or, if the recommendations were general, left to the Crown to decide. In South Africa this function is separate and allocated to the Minister of Land Affairs. Prior to the hearing the Minister must certify whether restoring the state or alternative state-owned land or acquiring a right in privately-owned land for the purposes of restoration is feasible. ${ }^{127}$ All interested parties are then entitled to make

122 See I MacDuff "The role of Negotiation : Negotiated Justice?" (1995) 25 VUWLR 144 for a discussion of negotiation and mediation in the New Zealand context. See also Durie n33, 100 where he says that the Tribunal has found that a matter should be referred only to mediation when the facts and issues are clear and settled and points out that mediation of large historic claims has largely been "subsumed by negotiations".

123 Above n25, s13.

124 Above n25, s14(1)

125 Above n25, s14(2)(b)

For example, if an agreement is reached of which the Court approves it will cover any legal costs incurred. 
submissions. In South Africa this is a very important stage of the process because much land is likely to be unusable due to environmental factors or development that has occurred. The Minister is therefore instructed to take into account such factors as any alteration to the land, relevant urban development plans and any physical or inherent defect in the land which would cause it to be dangerous to inhabitants. ${ }^{128}$ In comparison, the Tribunal is instructed not to take into account changes to the land or its ownership, possession or any other interest in it which have taken place immediately before the date of transfer of the land or land interest from the Crown to the State Enterprise ${ }^{129}$ or which have occurred after or by virtue of the granting of any Crown forestry licence in that land. ${ }^{130}$

\section{ADJUDICATION}

The Tribunal has to decide whether a claim is well founded and that is chiefly a matter of intensive historical research. In deciding on compensation it considers the land lost and in a broad way the impact of the loss. ${ }^{131}$

Adjudication by the Land Claims Court takes place on another level. The historical investigation will have been done by the Commission and the restoration or state acquisition, in the case of private land, of the right in land will have been certified as feasible or not. All that remains to be done in most cases is for the Court to rule on the recommendation and make an order as to costs. In the event of conflicting interests (where the State has certified the feasibility of acquiring private land) the Court will only order the State to acquire the land if it is just and equitable to do so, taking into account factors similar to those considered by the Waitangi Tribunal - the history of the loss, its effects and the present circumstances - but in an attempt to balance the two parties' interests. ${ }^{132}$ Existing rights of ownership do not have precedence over claims for

128 Above n25, s15(6).

129 Above $n 57, \mathrm{~s} 8 \mathrm{~A}(3)$.

130 Above $\mathrm{n} 57, \mathrm{~s} 8 \mathrm{HB}(2)$.

131 Factors taken into account include : the grievance from the manner of dispossession, injury by removal from ancestral holdings, lost development opportunities, and the loss of infrastructure and the formation of the human capital resource that usually accrues to those protected in their property enjoyment (Durie above $\mathrm{n} 4,14$ ).

132 Relevant factors include the desirability of providing for restitution or compensation (this is where the Land Claims Court Working Group's proposal of a "presumption" of restitution is built into the legislation) and of remedying past human rights violations, requirements of equity and justice, the desirability of avoiding major social disruptions, the existing provisions designed to by the Court (above n25 s33) achieve the goals contemplated in s8(3) of the Interim Constitution (regarding expropriation), and factors considered relevant and consistent with the spirits and objects of the Interim Constitution and in particular s8 (the property clause) in 
restitution. ${ }^{133}$

\section{FINDINGS AND REMEDIES}

Tribunal recommendations may be in general terms or may indicate in specific terms the action which the Tribunal thinks the Crown should take. ${ }^{134}$ In an interim report the Tribunal may recommend that the Crown and claimants negotiate and assist the negotiation with further hearings on remedies; a final report will comprise detailed recommendations on remedies. It is then up to the Crown if and how to put the recommendations into effect and the Tribunal has no further involvement. It makes not only recommendations but findings of fact and interpretation and in a sense advises both the relevant Ministers of the Crown and the public. ${ }^{135}$

It has no power to award costs; Durie suggests this is an advantage because it may deter genuine claimants. ${ }^{136}$ The wide discretion given to the Land Claims Court to make any order as to costs that is just, prevents such a result. It could elect to, among other things, not award costs against an unsuccessful party or to penalise parties for unnecessarily protracting the case, failing to attend a conference, comply with rules or to promote, to a material degree, the expeditious, economical and effective disposal of the case; or to penalise a party who has been guilty of objectionable or unprofessional conduct. $^{137}$

The Tribunal is not restricted to assessing loss and ordering recovery - an equivalence may be impractical - nor to recommending monetary compensation or recovery of Crown land. It may, instead, propose broad policies for long term restoration. ${ }^{138}$

In New Zealand the recommendation of compensation was influenced by the financial ceiling instituted by the government which forced the Tribunal to shift its focus to a broad consideration of the claims as a whole. ${ }^{139}$ Equitable apportionment has

addition to: the history of dispossession, the hardship caused by it, the circumstances of acquisition of land by its owner, the use to which it has been put, and the interests of the owner and the person dispossessed (1993 Constitution s123(2)).

Above n27, para 33.

Above n57, s6(4).

Above n24, 235.

Durie above n4, 14 .

Land Claims Court Rules, 21 February 1997, no 61.

Durie above n33, 97.

Although the "fiscal cap" has been formally removed by the new coalition government, the $\$ 1$ billion limit is still government policy. 
become important as a result ${ }^{140}$ and it is recognised that the economy cannot afford full compensation. ${ }^{141}$

The Land Claims Court may order the state to purchase or expropriate private land and restore it to the claimant. ${ }^{142}$ The land owner is entitled to just and equitable compensation from the state. If it is not feasible to restore the land claimed to the claimant, the Court may grant the claimant a right in alternative state-owned land, or order the state to pay the claimant just and equitable compensation. The Court has a wide discretion including a change in the form of right held by the claimant ${ }^{143}$ and the imposition of conditions which must be complied with before restoration or compensation. ${ }^{144}$ A successful claimant could instead be registered as a preferential claimant to benefit from any state support programme for housing and the allocation and development of rural land. ${ }^{145}$

\section{OPPORTUNITY TO TAKE THE CLAIM FURTHER}

There is no right of appeal against Tribunal decisions, even with regard to binding determinative powers. The only other avenue available is judicial review. Direct negotiation is always an option and one that is resorted to more often as claimants realise that the Tribunal is slow and expensive and they have to deal with the government at the end anyway. Section 9 of the 1975 Act specifically retains the right to petition Parliament.

If a person is dissatisfied with any decision of the South African Land Claims Court, an appeal can be made to the Constitutional Court or to the Supreme Court of Appeal (formerly the Appellate Division of the Supreme Court). None have been taken so far. Decisions and actions of the Commission and the Minister's decision on feasibility are both subject to review.

\section{CONSTRAINTS}

\section{A Delay}

Any such process will necessarily be time consuming by virtue of the nature of the subject-matter - land claims are sensitive, deeply embedded in their historical context and

\footnotetext{
140 Durie above $\mathrm{n} 4,15$.

141 Durie above $\mathrm{n} 4,16-17$. It is a matter of "pragmatic expedience".

142 Above n25, s35.

143 Above n25, s35(4).

144 Above n25, s35(2)(a).

145 Above n25, s35(2)(d).
} 
involve many conflicting issues and understandings of land concepts. The role of negotiations also contributes to making it a painstaking process. In New Zealand the gap between the hearing and the report is a problem - for example, the Whanganui hearing finished in 1994 but the report is still awaited. How much of a problem this becomes depends on education of the public and claimants that in reaching an equitable outcome it is preferable that the process be slow and careful, and on having the resources available to at least keep the claims moving so that the claimants feel that progress is being made. ${ }^{146}$

Seremane describes delays experienced by the Commission caused by what he tactfully refers to as the "ponderous workings of the public service and its accounting system". ${ }^{147}$ In South Africa the number of claims has exacerbated the bureaucratic and administrative problems. The need to screen out fraudulent claims, check that all potential beneficiaries are included and establish the identification of the actual piece of land claimed is necessary for the process to be just but means it will take time. ${ }^{148}$

\section{B Resources}

The Waitangi Tribunal is limited by lack of resources ${ }^{149}$ which has led to delays and backlog. ${ }^{150}$ The expense of research and preparation of claims will continue to hinder its progress. ${ }^{151}$ When Buddy Mikaere, former Director of the Tribunal, resigned he was critical of the lack of funding and said he believed many Tribunal members did not have

146 See "River anger blamed on Waitangi case delay" Dominion, Wellington, New Zealand, 8 January 1997, 2 where Maori protestors threw rocks at a houseboat on the Whanganui river and the confrontation was blamed on a three-year wait for a Waitangi Tribunal ruling on a claim over the river. See also "Solving grievances in a volatile environment" Evening Post, Wellington, New Zealand, 20 May 1995, 10 : frustration has been caused by perceived lack of progress, cynicism about the government's true intent and an overload of information.

Above n26, 4

Walker above n29, 47

See "Frustrated boss quits Tribunal" Evening Post, Wellington, New Zealand, 30 September 1995, 4 referring to Mikaere's frustration with "managing an under-resourced tribunal".

150 According to the Evening Post above n32, approximately 650 claims have been lodged since 1975 and there is a backlog of more than 450. See the Re The Ngai Tahu Claim - Wai-27, 17 March 1995, 12 where Ngai Tahu's request for urgency was denied because it had already hampered progress on other claims and the Tribunal had to be fair in allocating resources. In response Ngai Tahu took the Tribunal to the High Court in order to ensure they received priority (Evening Post above n146). This claim is on hold during negotiations with the Crown.

$151 \$ 500000$ is the average spent on research and legal costs in preparing a claim to take to the Tribunal - see "Maori land claim costs four times the norm" Dominion, Wellington, New Zealand, 26 March 1997, 14. Some hearings cost up to $\$ 25000$ a week (Evening Post above n32). 
the right skills for the job. ${ }^{152}$ In South Africa, the major constraint has not been budgetary but insufficient skilled and experienced staff, ${ }^{153}$ and the Commission is of the view that that is the only real obstacle in the way of its completing its task in the designated five years. ${ }^{154}$

\section{Limits on Power}

The Waitangi Tribunal is also constrained by the fact that it is dependent on legislation for its existence and the implementation of most of its work depends on the Crown. In comparison, in South Africa, because the final decision is up to the Court and the government will rarely oppose a recommendation, this inequality of power between parties does not arise.

\section{General}

It is too early to know exactly what problems the South African system will experience. The difficulties experienced in establishing the system indicate that it will not be trouble-free. Seremane describes "the seemingly insurmountable hurdles of suspicion, mistrust, impatience, inflated expectations and even greed and avarice". ${ }^{155}$

Unique problems experienced early in South Africa include land claim scams where the police have had to deal with instances where money has been paid for assistance offered in processing claims which did not materialise, ${ }^{156}$ resistance by some private landowners who have been unwilling to negotiate or litigate ${ }^{157}$ and the effect of private and public development. Many areas are developed beyond recognition and it is a difficult, if not impossible, task to even ascertain the boundaries of the original piece of land. There is also in many instances, a conflict between government policies where a claim is lodged for land that is earmarked for development, especially housing. ${ }^{158}$ Other

152 "Call for Tribunal Debate" Evening Post, Wellington, New Zealand, 14 May 1996, 2.

153 In the First Annual Report above n26, 10 the allocation of R14 051000 for the 1996/1997 financial year was said to already not be enough for professional services to provide a research capability for the Commission and for an effective publicity campaign. See also "Land Reform in South Africa" Agricultural News, 19 May 1997, 6.

154 Above $\mathrm{n} 26,9$

155 Above n26, 3 .

156 This has become less of a problem as awareness of the Commission's role in providing free assistance has spread.

157 Above n26, 12.

158 Walker above n29, 48 
issues are what to do about conservation land, ${ }^{159}$ social complexities (for example what the appropriate settlement should be where claimants include tenants and landowners ${ }^{160}$ ) and the development challenges facing the community once it is resettled. ${ }^{161}$

Divisions among claimants on many different levels (experienced in South Africa among different sections of a whole community removed, between more than one community and between tribal authorities claiming on behalf of people and ad hoc restitution committees) has also been a problem in New Zealand. ${ }^{162}$ In South Africa, there is also usually a division on racial lines between landowner and claimant.

A land claims process will never be free of problems. The success it achieves depends on how it deals with those problems and unfortunately this usually depends on resources. The money available to the Commission in South Africa will mean that more options will always be open to it. The Waitangi Tribunal is at a disadvantage because it is not backed financially to the same extent. Any evaluation of its progress must be mindful of the financial parameters within which it has to function.

\section{SUCCESSES}

It is early days yet for the South African Land Claims system and the context within which it is operating is very different to that of New Zealand. Its objectives are limited but the scale in terms of people, area and history must be daunting. It is likely to take a while to deal with all the grievances and even then is unlikely to find a solution which satisfies everyone. ${ }^{163}$ It remains to be seen whether in the context of the complexity and scale of its tasks and the seeming impossibility of solving them, it has been structured and given the powers to cope effectively. Its aim, however, is the restitution of land and if land is returned or compensated in some other way, it will be successful. The broader

159 In the Evening Post above n146 Federated Mountain Club president Hugh Barr is reported as saying the Tribunal sees the conservation estate "as a cheap and easy means of settling Treaty claims".

160 "Old schisms" may be reopened. Landowners may disagree amongst themselves as to whether tenants should be included in their settlement and tenants may feel they have a stronger claim, especially in cases of absentee landowners (Walker above n29, 49).

161 Communities will usually leave behind their houses, schools and clinics and have to live under rudimentary conditions.

162 For example the settlement of the Muriwhenua claim has been jeopardised by the inability of the five Far North tribes to agree (The Daily Post above n58, 4).

163 Maori Fisheries Commissioner, Shane Jones, says that this is in fact a measure of the Waitangi Tribunal's success - it has been "even-handed, alarming conservation interests but also disappointing Maori radicals" (Evening Post above n146). 
injustices suffered by the indigenous people are addressed in other forums - especially the Truth and Reconciliation Commission.

The Tribunal has a much wider focus. Land is not its sole concern. The real issue is the relationship between Maori and the government. ${ }^{164}$ Successful settlement is an important element but so is raising public awareness of Maori grievances. The emphasis is not on the quantum of loss but the impact of loss over time. ${ }^{165}$ In New Zealand the Tribunal is a vital instrument of reform with regard to the position of the Maori people.

Although some of the greatest advances for Maori in recent years have been through the courts, ${ }^{166}$ this is only where statute has allowed it. The Tribunal can recommend changes in statutes which the courts cannot. In practical terms, its influence can be seen in the rewriting of statutes, the restructuring of government departments and the departmental auditing of proposed legislation for consistency with Treaty principles. ${ }^{167} \mathrm{It}$ has featured regularly in the media and today no one can be excused for being ignorant of at least its basic aims and functions.

The Tribunal, in light of its limited powers and relatively vague objectives, must have exceeded everyone's expectations in terms of the farreaching effects of its reports and the status it has achieved in the New Zealand system.

\section{INTERNATIONAL CONTEXT}

Developments in the international arena add another dimension to the land claims processes in New Zealand and South Africa. There is a worldwide trend towards addressing such grievances ${ }^{168}$ and the international community has been slowly formulating its role with regard to indigenous people. Land rights have been recognised as deserving of special protection, in light of the affinity which indigenous people traditionally have with their territorial environment.

Section 27 of the Draft Declaration on the Rights of Indigenous People 1993 provides for a right to the restitution of land traditionally owned but confiscated, used or damaged

164 Waitangi Tribunal Taranaki Interim Report : Kaupapa Tuatahi - Wai-143 (Department of Justice, Wellington, 1996) 1.

165 Above n164, 14.

166 See for example, New Zealand Maori Council v Attorney-General above n20.

167 Durie and Orr above n47, 62-63.

168 Restitution has played a role with regard to land claims in the United States, Canada and Australia and has been an issue in the Central and Eastern European countries. See R Plant Land Rights and Minorities (Minority Rights Group International, London, 1994) 7. 
without their consent or where that is not possible, just and fair compensation. ${ }^{169}$ Although it is unlikely to be adopted in the near future and may have to be considerably altered first, it does show a trend towards an international recognition of indigenous rights and strengthens the position of the Tribunal.

\section{CONCLUSION}

The Waitangi Tribunal is the main avenue open for Maori grievances because the Maori Land Court and ordinary courts, which have the power to enforce the decisions they make, cannot question the system of which they are a part - they cannot question New Zealand's system of parliamentary supremacy and consequently the title to any land that has been acquired by legislation.

In comparison to the South African system, the Tribunal's position is quite precarious (at least in theory) and its lack of real power is striking. Yet it clearly has achieved much in light of the task and powers given it and appears to be well-suited to the New Zealand context with its emphasis on developing a partnership relationship.

With its power and resources, the South African system has the potential to deal successfully with the task facing it. It will be interesting to see how it adapts to the South African circumstances and their unique difficulties.

The question of land claims is complex and sensitive. Every alternative will raise its own set of problems. Only time and experience will reveal the most appropriate approach for each situation. Ultimately the most important function of these land claims mechanisms is to enable individual people and communities to work through the past and come to terms with the present so as to face the future with dignity and optimism. As long as they continue to do this they will have a role to play in the futures of their respective countries.

169 See also Article 14 of the International Labour Organisation Convention 169 adopted in 1989 Article 14(3) provides: "Adequate procedures shall be established within the national legal system to resolve land claims by the peoples concerned." New Zealand, along with many other countries is not a party to the Convention. 